\begin{tabular}{|c|c|c|c|c|c|c|}
\hline \multirow{4}{*}{ Impact Factor: } & ISRA (India) & $=3.117$ & SIS (USA) & $=0.912$ & ICV (Poland) & $=6.630$ \\
\hline & ISI (Dubai, UAE & $=0.829$ & РИНЦ (Russia & $=0.156$ & PIF (India) & $=1.940$ \\
\hline & GIF (Australia) & $=0.564$ & ESJI (KZ) & $=8.716$ & IBI (India) & $=4.260$ \\
\hline & JIF & $=1.500$ & SJIF (Morocco & $=5.667$ & OAJI (USA) & $=0.350$ \\
\hline
\end{tabular}

\section{SOI: $1.1 /$ TAS $\quad$ DOI: $10.15863 /$ TAS International Scientific Journal Theoretical \& Applied Science}

p-ISSN: 2308-4944 (print) e-ISSN: 2409-0085 (online)

Year: 2019 Issue: $03 \quad$ Volume: 71

Published: $19.03 .2019 \quad$ http://T-Science.org

UDC: $\mathbf{5 0 2 . 5}$

SECTION 11. Biology. Ecology. Veterinary.
QR - Issue
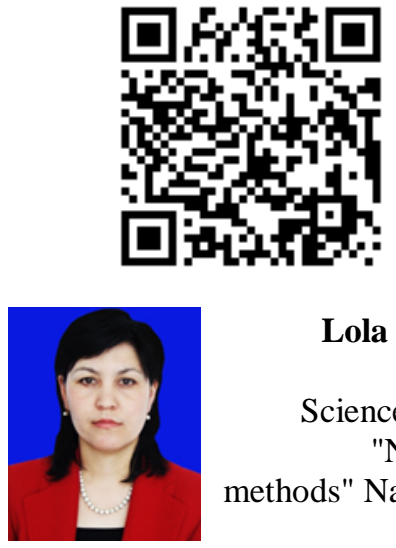

Lola Toktomuratovna Kamilova Candidate of Geographical

Sciences, head of the Department of

"Natural Sciences and teaching methods" Naturally Faculty of Education, Kyrgyz-Uzbek University, Osh, Kyrgyz Republic

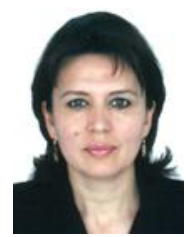

Gulchehra Sherbekovna Sabitova Senior Lecturer of the Department of "Natural Sciences and Techniques Learning» Naturally-pedagogical faculty, Kyrgyz-Uzbek University,

Osh, Kyrgyz Republic

\title{
ECOLOGICAL CONDITION OF SOILS AT THE STAGE OF ECONOMIC DEVELOPMENT OF KYRGYZSTAN
}

Abstract: In the article a problem is examined about the ecological state of soils on territory of Kyrgyzstan. Authors expose such questions as analysis of the ecological state of soils, reason of degradation of soils. As a table cited data about quality description of soils on the areas of Kyrgyzstan. The special meaningfulness in the article is occupied by suggestions on the improvement of composition and properties of soils on territory of Kyrgyzstan.

Key words: Ecological state of soils, degradation processes, quality description of soils, increase of the productivity of earth, events on soil-amendment.

Language: Russian

Citation: Kamilova, L. T., \& Sabitova, G. S. (2019). Ecological condition of soils at the stage of economic development of Kyrgyzstan. ISJ Theoretical \& Applied Science, 03 (71), 348-351.

Soi: http://s-o-i.org/1.1/TAS-03-71-22 Doi: crossef https://dx.doi.org/10.15863/TAS.2019.03.71.22

\section{ЭКОЛОГИЧЕСКОЕ СОСТОЯНИЕ ПОЧВ НА ЭТАПЕ ЭКОНОМИЧЕСКОГО РАЗВИТИЯ КЫРГЫЗСТАНА}

Аннотация: В статье рассматривается проблема по экологическом состоянии почв на территории Кыргызстана. Авторы раскрывают такие вопросы как анализ экологического состояния почв, причины деградации почв. В виде таблицы приведены данные о качественной характеристике почв по областям Кыргызстана. Особую значимость в статье занимают предложения по улучшению состава и свойств почв на территории Кыргызстана.

Ключевые слова: Экологическое состояние почв, дегредациионые процессы, качественная характеристика почв, повышение производительности земель, мероприятия по улучшению почв.

\section{Introduction}

Кыргызстан расположен в верховьях Среднеазиатской экологической системы, поэтому охрана и рациональное использование его природных ресурсов имеет огромное значение для сбалансированного, стабильного протекания геологического и биотического круговорота веществ во всей этой системе. В последние годы, в связи с быстрым ростом численности народонаселения, почвенный покров региона начал испытывать мощное антропогенное и технологическое воздействие. Чрезмерная эксплуатация пастбищ, освоение в орошаемое земледелие новых участков земель, применение ядохимикатов и удобрений нарушают сложившиеся биосферные 


\begin{tabular}{|c|c|c|c|c|c|c|}
\hline \multirow{4}{*}{ Impact Factor: } & ISRA (India) & $=3.117$ & SIS (USA) & $=0.912$ & ICV (Poland) & $=6.630$ \\
\hline & ISI (Dubai, UAE & $=0.829$ & РИНЦ (Russia & $=0.156$ & PIF (India) & $=1.940$ \\
\hline & GIF (Australia) & $=0.564$ & ESJI (KZ) & $=8.716$ & IBI (India) & $=4.260$ \\
\hline & JIF & $=1.500$ & SJIF (Morocco & $=5.667$ & OAJI (USA) & $=0.350$ \\
\hline
\end{tabular}

равновесия и зачастую приводят к негативным последствия (уничтожение полезной естественной растительности, развитие эрозии почв, загрязнение почвы и водоемов и т. д.). Охрану почв Кыргызстана следует рассматривать как единую систему мероприятий, направленную на защиту, качественное улучшение и рациональное использование его земельных ресурсов [2, С.136].

\section{Materials and Methods}

Общая площадь Кыргызстана - 19995,1 тыс. га. Общая площадь сельскохозяйственных угодий Кыргызской Республики, по состоянию на 1 января 2011 года составляет 10650,8 тыс. га (53 \% всего земельного фонда), которые по государственному земельному учету числятся в разных категориях земель, в том числе:

- Пашни 1276,2 тыс. га

- Многолетние насаждения 44,2 тыс. га

- Залежи 38,9 тыс. га

- Сенокосы 168,4 тыс. га

- Пастбища 9064 тыс. га

- Кроме того:

- Лесные площади 1164,1 тыс. га

- Древесно-кустарниковые насаждения 463,5 тыс. га

- Болота 6,2 тыс. га

- Прочие 7648,8 тыс. га

В составе угодий наибольшую площадь 85,3 $\%$ от площади сельскохозяйственных угодий, составляют пастбища, площадь которых постоянно уменьшается.

Система ведения сельского хозяйства - один из важнейших факторов, воздействующих на качество почв, урожайность и соответственно уровень бедности населения. Об этом было отмечено национальном докладе о состоянии окружающей среды Кыргызской Республики за 2006-2011 годы. Докладе были представлены показатели состояние сельскохозяйственных угодий и экологическое состояние почв. Настоящее время настоящее время земельные сельскохозяйственные угодья подвергаются к дегредационным процессам. Основными причинами являются следующее:

- Подвержение эрозией. Эрозия является результатом неустойчивого использования сельскохозяйственных земель, деятельности крупных хозяйств, чрезмерного выпаса скота, а также неэффективных систем ирригации и управления водным хозяйством.

- Система ведения сельского хозяйства. Это важнейший фактор который воздействует на качества почв. Неблагоприятное воздействие ведет к потере продуктивности растениеводства и зачастую необратимому ущербу для почв.

- Снижению

биологической

продуктивности. К снижению биологической продуктивности влияет эрозионные процессы, засоление и заболачивание.

- Сильное расчленение территории Кыргызстана. Причиной расчленения является географический рельеф Кыргызстана.

- Антропогенный фактор. Развитие эрозионных процессов непосредственно связаны с хозяйственной деятельностью человека и, особенно, с неправильным использованием поливных земель. Сильный смыв и размыв почвы происходят при несоблюдении приемов противоэрозионной обработки почвы и при нерациональном размещении сельскохозяйственных культур.

Внедрения научно-

обоснованной системы земледелия, освоения новых земель, улучшения сенокосов и пастбищ, планирования и проведения мелиорации, разработки обоснованных систем агротехники и достижения максимальной согласованности сельскохозяйственного производства с природными условиями и качеством земель составляется на основе составления подробного описания состава и свойств почв Кыргызстана. Ниже представлена таблица, где представлены качественная характеристика почв по областям $[5,125]$.

Качественная характеристика почв по областям Кыргызстана, тыс. га (2010 г.)

\begin{tabular}{|l|c|c|c|c|c|c|}
\hline $\begin{array}{c}\text { Наименование } \\
\text { областей }\end{array}$ & $\begin{array}{c}\text { Засолен } \\
\text { ные }\end{array}$ & $\begin{array}{c}\text { Солонце } \\
\text { ватые }\end{array}$ & $\begin{array}{c}\text { Заболо } \\
\text { чен } \\
\text { ные }\end{array}$ & $\begin{array}{c}\text { Каме } \\
\text { нис } \\
\text { тые }\end{array}$ & $\begin{array}{c}\text { Дефляционно- } \\
\text { опасные } \\
\text { (ветровая } \\
\text { эрозия) }\end{array}$ & $\begin{array}{c}\text { Подверж. } \\
\text { водной эрозии }\end{array}$ \\
\hline $\begin{array}{l}\text { Джалал- } \\
\text { Абадская }\end{array}$ & 16,2 & 6,1 & 2,0 & 610,8 & 861,0 & 867,3 \\
\hline Ошская & 3,3 & 0,2 & 0,8 & 26,2 & 92,0 & 134,8 \\
\hline & 77,3 & 15,6 & 9,8 & 685,3 & 830,6 & 874,7 \\
\hline Баткенская & 27,4 & 1,6 & 8,8 & 26,7 & 89,3 & 78,4 \\
\hline & 11,9 & 11,3 & 14,7 & 320,2 & 447,2 & 367,5 \\
\hline
\end{tabular}




\begin{tabular}{|c|c|c|c|c|c|c|}
\hline \multirow{4}{*}{ Impact Factor: } & ISRA (India) & $=3.117$ & SIS (USA) & $=0.912$ & ICV (Poland) & $=6.630$ \\
\hline & ISI (Dubai, UAE & $=0.829$ & РИНЦ (Russia & $=0.156$ & PIF (India) & $=1.940$ \\
\hline & GIF (Australia) & $=0.564$ & ESJI (KZ) & $=8.716$ & IBI (India) & $=4.260$ \\
\hline & JIF & $=1.500$ & SJIF (Morocco & $=5.667$ & OAJI (USA) & $=0.350$ \\
\hline
\end{tabular}

\begin{tabular}{|l|c|c|c|c|c|c|}
\hline $\begin{array}{l}\text { Ыссык- } \\
\text { Кульская }\end{array}$ & 84,3 & 1,9 & 40,4 & 429,0 & 1026,7 & 823,1 \\
\hline & 16,0 & 0,6 & 9,0 & 23,4 & 130,9 & 92,1 \\
\hline Нарынская & 674,1 & 332,3 & 28,1 & 1210,0 & 1066,7 & 1628,6 \\
\hline & 16,1 & 11,5 & 0,5 & 44,7 & 76,0 & 217,5 \\
\hline Таласская & 15,4 & 7,2 & 5,0 & 451,4 & 711,4 & 626,9 \\
\hline & 5,6 & 6,5 & 0,5 & 13,6 & 94,2 & 73,9 \\
\hline Чуйская & 286,1 & 96,8 & 18,6 & 314,5 & 746,2 & 438,7 \\
\hline & 160,0 & 60,0 & 0,3 & 38,6 & 138,5 & 134,6 \\
\hline По республике & $\mathbf{1 1 8 0 , 8}$ & $\mathbf{4 7 1 , 2}$ & $\mathbf{1 1 8 , 6}$ & $\mathbf{4 0 2 1 , 2}$ & $\mathbf{5 6 8 9 , 8}$ & $\mathbf{5 6 2 6 , 8}$ \\
\hline & $\mathbf{2 2 0 , 0}$ & $\mathbf{8 1 , 8}$ & $\mathbf{3 3 , 1}$ & $\mathbf{1 9 6 , 1}$ & $\mathbf{6 5 1 , 1}$ & $\mathbf{7 6 4 , 8}$ \\
\hline
\end{tabular}

Примечание: иифра выпе - все земли сельскохозяйственных предприятий; цифра ниже - орошаемые земли сельскохозяйственных предприятий

Повышение производительности земель Кыргызстана на прямую зависит от экологического состояние почв, которая может быть достигнута как путем трансформации менее ценных угодий в более ценные, так и путем мелиорации почв без изменения характера использования территории. С учетом природных условий каждого вертикального почвенноклиматического пояса, а также состава и свойств почв на территории Кыргызстана рекомендуются следующие организационно-хозяйственные, лесомелиоративные и пастбищномелиоративные мероприятия.

Организационно - хозяйственные мероприятия:

- правильная организация территории сельскохозяйственного использования с учетом термического пояса, состава и свойств почв;

- специализация сельскохозяйственного производства на орошаемых землях в области: кормопроизводства - в холодном и умеренно холодном поясах; кормопроизводства, картофелеводства, овощеводства - в умеренно теплом поясе; кормопроизводства, табаководства, садоводства, овощеводства - в теплом поясах;

- совершенствование структуры посевов, сокращение площадей, занятых под нерентабельные культуры;

- укрупнение поливных участков и улучшение их конфигураций путем проведения капитальных планировок, переустройства примитивной оросительной сети;

- улучшение состояния и состава лесных и многолетних насаждений;

- правильная организация выпаса скота, улучшение пастбищ;

- переустройство дорожной сети, правильное размещение хозяйственных построек, ферм, поселков и т.д.

\section{Агротехнические мероприятия:}

- подбор камней на средне- и сильнокаменисто-скелетных орошаемых почвах и вывоз их за пределы орошаемой территории, что приведет к увеличению плодородия почв на $10-$ $30 \%$;

- внедрение полезащитных севооборотов с участием многолетних трав;

- внесение местных и минеральных удобрений на основании агрохимических карт с учетом степени нуждаемости почв и возделываемых культур в них;

- механизация сельскохозяйственных работ на укрупненных поливных участках;

- дифференциация поливных режимов с учетом степени каменистости и скелетности почв и гранулометрического состава мелкозема, а на аллювиально-луговых почвах — и с учетом глубины залегания грунтовых вод;

- внедрение противоэрозионной техники поливов на орошаемых почвах, подверженных эрозии (проведение обработок, посева и поливов поперек склонов).

\section{Гидротехнические и гидромелиоративные мероприятия:}

- строительство коллекторно-дренажной сети на территории пойменных террас и освоение в орошаемое земледелие всех неорошаемых аллювиально-луговых почв;

- проведение берегоукрепительных работ на крупных реках для охраны от размыва и затопления участков аллювиально-луговых и аллювиально-галечниковых почв;

- расширение русел горных потоков, опасных в селевом отношении и строительство селепроводящих каналов, мостов и т.д.;

- расширение и очистка существующих ирригационных каналов с целью улучшения их водопропускной способности;

- строительство плотин на малых горных речках для улучшения водоснабжения привязанных к ним земель;

- вовлечение в орошаемое земледелие сильнокаменисто- скелетных почв, конусов выноса горных речек, с последующим 


\begin{tabular}{|c|c|c|c|c|c|c|}
\hline \multirow{4}{*}{ Impact Factor: } & ISRA (India) & $=3.117$ & SIS (USA) & $=0.912$ & ICV (Poland) & $=6.630$ \\
\hline & ISI (Dubai, UAE & $=0.829$ & РИНЦ (Russia & $=0.156$ & PIF (India) & $=1.940$ \\
\hline & GIF (Australia) & $=0.564$ & ESJI (KZ) & $=8.716$ & IBI (India) & $=4.260$ \\
\hline & JIF & $=1.500$ & SJIF (Morocco & $=5.667$ & OAJI (USA) & $=0.350$ \\
\hline
\end{tabular}

использованием под многолетние травы и многолетние насаждения;

- промывка средне- и сильнозасоленных аллювиально- луговых орошаемых почв.

Лесомелиоративные мероприятия:

- создание лесных полос вдоль берега р. Нарын, Чу, Кара - Буура, Кара-Дарья, Ак-Буура, Сох и др.

для охраны почв от размыва, ветровой эрозии;

- посадка деревьев вдоль всех имеющихся в хозяйствах оросителей;

- освоение всех непригодных для земледелия пойменных участков долин крупных горных рек под культурные посадки облепихи;

- создание культурных посадок фисташек, ореха и других лесных насаждений в поясе горных коричневых, горных сероземах в ДжалалАбадской облати.

Пастбищно-мелиоративные мероприятия:

- нормирование нагрузки поголовья скота с учетом урожайности поедаемых трав;

- внедрение пастбищеоборотов, ограничение пастбищь скота во влажные периоды года;

- поверхностное улучшение пастбищ путем подсева ценных в корковом отношении дикорастущих и культурных трав и внесение удобрений;

- коренное улучшение пастбищ путем их залужения.

Вышеуказанные мероприятия способствуют улучшению экологического состояния почвы. На сегодняшний день почва определяется не только своей хозяйственной значимостью для сельского, лесного и других отраслей народного хозяйства; она определяется также незаменимой экологической ролью почвы как важнейшего компонента для всех наземных биоценозов и биосферы. Через почвенный покров земли идут многочисленные экологические связи всех живущих на земле организмов (в том числе и человека) с литосферой, гидросферой и атмосферой [1, 662].

В завершении можно сказать, что почва создавалась веками и тысячелетиями она является колоссальным природным богатством, обеспечивающее человека продуктами питания, животных - кормами, а промышленность сырьем. Чтобы правильно использовать почву, надо знать, как она образовывалась, ее строение состав и свойства. Почва обладает особым свойством - плодородием, она служит основой сельского хозяйства республики. Почва при правильной эксплуатации не только не теряет своих свойств, но и улучшает их, становится более плодороднее.

Из всего выше сказанного ясно, как велики и разнообразны роль и значение почвы в народном хозяйстве и вообще в жизни человеческого общества. Так, что охрана почв и их рациональное использование, является одной из важнейших задач всего человечества.

\section{References:}

1. Gerasimov, I. P. (1948). O tipah pochv gornyh stran i vertikal'noj zonal'nosti. Pochvovedenie, № 11, 661-669.

2. Kochurov, B. I. (2003). Jekodiagnostika $i$ sbalansirovannoe razvitie. (p.384). M.Smolensk: Madzhenta.

3. Kochurov, B. I. (1999). Geojekologija: jekodiagnostika i jekologo-hozjajstvennyj balans territorij. (p.154). Smolensk: SGU.

4. Kochurov, B. I. (1997). Geografija jekologicheskih situacij (jekodiagnostika territorij). (p.156). Moscow: IG RAN.

5. (1998). Kyrgyzskaja Respublika: "Gosudarstvennaja programma po ohrane okruzhajushhej sredy $i$ racional'nomu ispol'zovaniju prirodnyh resursov v Kyrgyzskoj Respubliki 2006-2011 gg.". Bishkek.

6. Mamytov, A. M. (1982). Pochvy gor Srednej Azii $i$ Juzhnogo Kazahstana. (p.250). Frunze: Ilim.

7. Romashkevich, A. I. (1988). Gornoe pochvoobrazovanie $i$ geomorfologicheskie processy. (p.150). Moscow: Nauka.

8. Sturman, V. I. (2000). Jekologicheskoe kartografirovanie. (p.152). Izhevsk: Udmurt. un-t. 